\title{
Competitiveness of innovation-driven economies: Insights from selected European countries
}

\author{
Maria Urbaniec
}

\begin{abstract}
A B S T R A C T
Objective: The aim of this paper is to analyse the role of innovation in competitiveness development and to identify the most competitive European economies. From the perspective of contemporary challenges, the following research question will be considered: How innovations determine development of the most competitive European economies?
\end{abstract}

Research Design \& Methods: Besides employing critical literature analysis, the research methods based on quantitative synthesis will also be used. Interpretations are developed through an in-depth comprehensive review of different studies and secondary data analysis.

Findings: The results provide valuable insights into how innovations determine development of the most competitive European economies. Measuring competitiveness relies on taking into account both supply-side and demand-side indicators. Based on the $\mathrm{GCl}$ both the demand-side as well as the supply-side innovation indicators were identified.

Contribution \& Value Added: The novelty of the study consists, on the one hand, in developing the conceptual framework for innovative competitiveness that contributes to the shaping of socioeconomic transitions and, on the other hand, in determining the innovation-driven factors of the most competitive European countries.

\begin{tabular}{|c|c|}
\hline Article type: & research paper \\
\hline Keywords: & $\begin{array}{l}\text { competition; competitiveness; innovation; innovation-driven econ- } \\
\text { omies; innovative competitiveness; Global Competitiveness Index }\end{array}$ \\
\hline JEL codes: & 010, 030, 052 \\
\hline Article & Article accepted: 1 September 2019 \\
\hline
\end{tabular}

\section{Suggested citation:}

Urbaniec, M. (2019). Competitiveness of innovation-driven economies: Insights from selected European countries. International Entrepreneurship Review (previously published as International Entrepreneurship / Przedsiębiorczość Międzynarodowa), 5(3), 113-127. https://doi.org/10.15678/IER.2019.0503.08 


\section{INTRODUCTION}

The shaping of economic policy conditions is the subject of research in various economic approaches. Dominated by Anglo-Saxon economists for over a century, the discussion on economic policy is reflected in classical liberalism, neoclassical theory, as well as Keynesianism. One of the elements influencing the shaping of socioeconomic development is market competition. Competition is perceived as a factor determining not only socioeconomic order at the macroeconomic level, but also the microeconomic developments fostering entrepreneurship and economic activity (De Soto, 2008). This stimulates the innovative actions of enterprises, resulting from adaptation processes to the changing conditions of socioeconomic development (Atkinson, 2013; Urbaniec, 2018).

The article aims to analyze the role of innovation in competitiveness development and to identify the most competitive European economies. This paper provides, on the one hand, theoretical insights into how innovations determine competitiveness development and, on the other hand, it examines innovation-driven factors influencing the most competitive European economies. Aside from employing critical literature analysis, conventional research methods of quantitative synthesis have also been used. Interpretations are developed through an in-depth comprehensive review of different studies and secondary data analysis.

Given the research topic, first, the role of market competition and competitiveness will be presented. In the next step, an attempt will be made to outline the concept of innovative competitiveness from the viewpoint of enterprises that are not only considered as significant entities of the national economy, but also key participants of the market process. After that, the influence of innovation-driven factors on the competitiveness of selected European economies based on the Global Competitiveness Index ( $\mathrm{GCl}$ ) will be analyzed. Finally, the discussion of the research results and conclusion will be presented.

\section{LITERATURE REVIEW}

\section{The role of competition and competitiveness in socioeconomic development}

The phenomenon of competition occurs in many areas of everyday life: social, political, economic, cultural, etc. It forms the basis for the functioning and development of the market economy. Competition is related to both the entire economy and the entities operating in it. According to many economists, it is the main method by which basic problems facing modern man can be solved. Market competition is seen as a procedure for discovering what is available to individuals, but unavailable to the public at large (von Hayek, 2002). Due to the fact that competition is inextricably linked to market processes, it is subject to constant changes dependent on various factors contributing to its development or limitations (Listra, 2015). Among the essential determinants (Porter \& Rivkin, 2012), the following can be listed:

- the integration of countries and economies around the world, into economically competing groups,

- the globalisation of economic processes,

- the liberalisation of the administrative policy of states,

- the creation of new "carriers" of competitiveness, e.g. the new perception of knowledge as a source of information and competitive advantage. 
Competition encourages firms to produce high-quality goods and services at the lowest possible price. The ability of firms to adjust is a measure of their efficiency as well as their competitiveness (UNCTAD, 2009). Therefore, competition is perceived as a key driver of competitiveness (Stiglitz, 2002). The review of the literature shows several concepts and theories of competitiveness. On the one hand there is a nation's competitiveness from the macroeconomic perspective, and on the other hand the firm competitiveness (microeconomic level). The $\operatorname{OECD}(1996$, p. 62) defines competitiveness as "the ability of companies, industries, regions, nations or supranational regions to generate, while being and remaining exposed to international competition, relatively high factor income and factor employment levels on a sustainable basis". The World Economic Forum (WEF, 2017, p. 11) determines competitiveness as "the set of institutions, policies, and factors that determine the level of productivity of an economy, which in turn sets the level of prosperity that the economy can achieve".

Competitiveness can be affected by many others factors, which have been of interest to economists for over two centuries, commencing with the seminal work by Adam Smith (1776). Recent empirical research has been referred mostly to the determinants of firm's competitiveness (Siudek \& Zawojska, 2014), probably due to the fact that firms (and not individual nations) compete on international markets, as also claimed by Porter (1990). Generally, it can be stated that success or the lack thereof, in the process of socioeconomic development, is determined by what is taking place in enterprises. In the current era of globalisation, enterprises endeavour to constantly search for and create ventures enabling them to cope with the dynamically developing and complex environment (Porter, 1990). In addition, they also seek to achieve such a systemic reconstruction and change in their structure that would allow them to acquire new features and take actions necessary for their transformations and expansions. Enterprises, as part of the economic and political order, are subject to constant changes resulting from dynamic socioeconomic conditions. Therefore, the functioning of the enterprise is the basis of the economic process and a central element of the entire subjective structure of the economy. The key distinguishing feature of enterprises is the fact that they contribute to creating the largest portion of the national income, and the rationality and effectiveness of their management depends on the standard of living of the entire society (Steckel, 1995). Based on the literature analysis, it can be presumed that the competitiveness is a chief determinant conducive to the socioeconomic development.

\section{Conceptual framework of the innovative competitiveness}

The essence of competitiveness is an innovative activity. J.A. Schumpeter emphasised that, owing to market-driven competitiveness and the introduction of constantly "new, often revolutionary" combinations of production factors by "new pioneers", the market economy may develop dynamically (Schumpeter, 2008). This is accompanied not so much by stability and balance, but rather imbalance and instability (Schumpeter, 1934).

The process strictly connected with the essence of the market mechanism, which manifests itself in various forms of competitiveness, enabling an improvement of the economy development in both quantitative and qualitative terms, is termed "creative destruction". It is reflected in Schumpeter's concept of the entrepreneur (routine breaker), whose motivation to implement innovations results not only from planned profits, but also from internal encouragement to take actions (Diamond, 2006; Reinert \& Reinert, 2012; Vivarelli, 
2013; Block, Fisch \& van Praag, 2017). The process of "creative destruction" therefore includes two aspects. Firstly, "creative destruction", through innovation, selects enterprises in terms of their skills. Secondly, it defines the size of the innovative activity of rival companies. Schumpeter's "creative destruction" process illustrates that the innovative advantage is considered to be the chief source of economic growth and development. The ability to achieve this type of advantage is a result of intensifying the creation of innovations by gaining a monopolistic market position. According to Schumpeter, those large enterprises and monopolies dominating in the market are more likely to be innovative, whose technological advantage results chiefly from the internal potential of the enterprise, e.g. research and development activities (Schumpeter, 2008). Thus, "creative destruction" is a process that is beneficial in terms of dynamics and efficiency of the development processes, which is reflected in the modernisation of the economy, gaining technological advantages and such changes in structure that demonstrate the growing level of innovation.

In the current era of economic processes, the nature and intensity of various innovative ventures that adapt the behaviour of enterprises to the requirements of the market economy and the state, structure, complexity and dynamics of their surroundings, are decisive for the development of each enterprise (Urbaniec \& Gerstlberger, 2011). Innovations can be considered in terms of subject and process. In terms of subject matter, the Schumpeter's definition of innovation include (Schumpeter, 1934):

- introduction of a new product (or modification of a pre-existing one),

- introduction of a new production method,

- new outlet where a certain branch has not yet been represented,

- obtaining of new sources of raw materials or semi-finished products, without paying attention of whether the source already exists or is completely new,

- changes in market organisation.

In terms of process, innovation includes the primary economic realisation of the invention underlying it, i.e. implementation into the economy. According to what is referred to as "Schumpeter's triad", technical changes are divided into: 1) invention, 2) innovation, 3) imitation. Invention requires the expenditure of certain inputs (technology-input), owing to which it is transformed into a technical product in the form of product and process innovation (technology-output), and then disseminated into the enterprise, branch, economy or the world (diffusion). The invention measurement is the sum of R\&D expenditures, while the measurement of the final effect is based on the number of licenses or know-how (Schumpeter, 1939). Process innovation has been the subject of broad discussion since Schumpeter's time. One of the aspects of the innovation process is its division into (Mowery \& Rosenberg, 1979; Edler \& Yeow, 2016):

- a supply-side model, based on the neoclassical growth theory (close to the Schumpeterian concept), pointing to the need to implement research and development (R\&D) processes that are innovative in nature,

- a demand-side model, resulting from the post-Keynesian economy assumptions, according to which the most important mechanism for enterprises is the realisation of market needs. Innovations are treated as a response to new economic opportunities to maximise company profit. 
Each enterprise has its own methods of achieving the effects of innovations that may result from both supply-side and demand-side factors. In addition, the innovative process is matched to the market and its participants operating in a given period. The effect of the changes is a new company structure resulting from lower production costs and benefits from new technologies, as well as a new general economic order related to the creation of a new market. Both the supply-side and demand-side factors drive innovation significantly, but their role in influencing the types and outcome of the innovation process can be different (Miles \& Rigby, 2013).

In the report by the Business Innovation Observatory (European Union, 2013), it was indicated that technologies enabling new business and production model trends already exist. Therefore, increasing efficiency and utilising potential is not dependent on additional R\&D support (supply-side innovation policy). An obstacle in the use of new production processes and business models can rather be seen in the scepticism and conservatism of potential customers. This requires more demand-side policy. Edler and Georghiou (2007, p. 952) define the demand-side innovation policies as "a set of public measures to increase the demand for innovations, to improve the conditions for the uptake of innovations, or to improve the articulation of demand in order to spur innovations and the diffusion of innovations". In line with this, there is a need for demand-side innovation policies in order to scale up new model trends, and thus competitiveness and socioeconomic benefits. The future impact of more demand-side policy efforts will generate greater growth and competitiveness for companies driving new trends.

It should be added that the creation of new economic opportunities or new technological solutions is the result of dynamic, innovative competitiveness. Innovative competitiveness leads to the greater utility of future products and their improved use, owing to which both the low-cost (low-tech) and more expensive (more innovative) market can be created. It can be assumed that innovative competitiveness is dependent on both demand-side and supply-side innovation factors.

The concept of innovative competitiveness can be defined as a cumulative phenomenon of innovation and competitiveness. It indicates the directions of innovation policy and businesses development, taking into account qualitative changes and potential to create new market solutions, in terms of technology, organisation or marketing. Given the conceptual framework, the innovative competitiveness is shaped by both demand-side and supply-side innovation factors. The supply-side factors result from: R\&D grants, tax credits (mostly for R\&D), incubator services, soft loans, competition awards and prize-money, public procurement of innovation schemes, networking events (European Union, 2013). Moreover, the demand-side innovation factors are pertinent to: regulation (use of regulation, standardisation), direct or indirect financial support for the purchase of innovations, public procurement of innovation, various types of training, and awareness mechanisms to improve the shaping of conductive regulatory framework conditions (Edler, Georghiou, Blind \& Uyarra, 2012). The combination of both the demand-side and the supply-side determinants is conducive to development of innovative competitiveness. This is necessary to achieve a dynamic path of innovation due to the growing complexity and variability of their macro-, meso- and microenvironment, as well as increasing market competition. 


\section{MATERIAL AND METHODS}

The article aims to identify the most competitive European economies and to analyse the role of innovation in their competitiveness development. The key question arising from this research objective is how innovations determine development of the most competitive European economies. This article also attempts to determine innovation-driven factors influencing the competitiveness of these countries.

The study was conducted by using of different research methods. Aside from employing critical analysis, conventional research methods of deduction, reduction and synthesis were additionally applied. Interpretations were developed through an indepth comprehensive review of different studies. The research analysis is based on secondary data. For selection and evaluating secondary data a set of criteria were used, e.g.: methodology, accuracy, date of data collection, purpose of data collection, data content (Crowther \& Lancaster, 2008).

According to this criteria, secondary data from a survey conducted by the World Economic Forum (WEF) within the Global Competitiveness Index (GCI) were selected. The $\mathrm{GCI}$ includes a wide array of determinants of a country's productivity, and reflects the complexity of the socioeconomic development process at both the macro- and microeconomic levels. The methodological approach employed by the $\mathrm{GCI}$ reflects a normative approach focused on stimulating discussion about political priorities, and supporting research in this area. The 2017 edition of the GCl Survey captured, in total, the views of 12,775 business executives from various sectors of activity: agriculture, manufacturing industry, non-manufacturing industry (mining and quarrying, electricity, gas and water supply, construction), and services, gathered in 137 countries. Given the selected European countries in this study, the 2017 surveys were carried out among 446 respondents (Switzerland - 52 respondents, the Netherlands - 78 respondents, Germany - 112 respondents, Sweden - 71 respondents, the United Kingdom - 83 respondents, and Finland - 50 respondents) (WEF, 2017).

Competitiveness is measured using different indicators contained in 12 components such as: institutions, infrastructure, macroeconomic environment, health and primary education, higher education and training, goods market efficiency, labour market efficiency, financial market development, technological readiness, market size, business sophistication, and innovation, that provide a comprehensive picture of the competitiveness landscape (Figure 1). These components are grouped into three sub-indexes: basic requirements, efficiency enhancers, and innovation and sophistication factors, which refer to different stages of economic development, i.e. factor-driven, efficiency-driven, as well as innovation-driven economies. All countries, chosen for the further analysis, were classified into innovation-driven economies.

Given the research objective of the article, in particular the innovation component is important for further analysis. The research methodology included three stages. In the first step, attention was drawn to indicate ten of the highest-ranking countries in the $\mathrm{GCl}$ (known as the top ten economies). Next, the most competitive European economies (six countries) were identified and selected taking into account only the innovation component. Finally, the innovation-driven indicators influencing the competitiveness of the European economies were analysed. 


\begin{tabular}{|c|c|c|}
\hline \multicolumn{3}{|c|}{ The Global Competitiveness Index } \\
\hline $\begin{array}{l}\text { Basic requirements } \\
\text { sub-index }\end{array}$ & $\begin{array}{c}\text { Efficiency enhancers } \\
\text { sub-index }\end{array}$ & $\begin{array}{c}\text { Innovation and sophistication } \\
\text { factors sub-index }\end{array}$ \\
\hline $\begin{array}{l}\text { - Institutions } \\
\text { - Infrastructure } \\
\text { - Macroeconomic environment } \\
\text { - Health and primary education }\end{array}$ & $\begin{array}{l}\text { - Higher education and training } \\
\text { - Goods market efficiency } \\
\text { - Labour market efficiency } \\
\text { - Financial market development } \\
\text { - Technological readiness } \\
\text { - Market size }\end{array}$ & $\begin{array}{l}\text { - Business sophistication } \\
\text { - Innovation }\end{array}$ \\
\hline$\downarrow$ & $\downarrow$ & $\downarrow$ \\
\hline $\begin{array}{l}\text { Key for factor-driven } \\
\text { economies }\end{array}$ & $\begin{array}{c}\text { Key for efficiency-driven } \\
\text { economies }\end{array}$ & $\begin{array}{l}\text { Key for innovation-driven } \\
\text { economies }\end{array}$ \\
\hline
\end{tabular}

Figure 1. The analytical framework of the Global Competitiveness Index Source: own study based on WEF (2017).

The employment of secondary data analysis to determine the role of innovative competitiveness in the socioeconomic development of the European economies is the right approach for many reasons. Firstly, these data include extensive test research regarding a large number of enterprises in different countries and from various industries. It is to stress that the high sample size, representativeness and number of observations leading to broader applications provide sufficient information to assess the external validity of the data. Moreover, external validity can be considered as a generalizability of the research results (Bryman \& Bell, 2007; Crowther \& Lancaster, 2008). Validity is important because it can help to determine using methods that are not only ethical and cost-effective, but also methods that truly measure the research idea or construct. In this study, the innovation-related issues in context of competitiveness are the main research construct. Secondly, the secondary data enables not only to describe reality but also to verify previously accumulated knowledge based on publicly available data. This leads to high quality results through the possibility of eliminating questionable and incomplete materials, and reduce the risk of participating in the study by people with limited knowledge and competence (Vartanian, 2011; Johnston, 2014). Thirdly, existing data support re-examination, and thus create the possibility of replication. This is especially important in providing the reliability of the research analysis (Easterby-Smith, Thorpe \& Lowe, 2002; Crowther \& Lancaster, 2008). It should be emphasized that the use of secondary data analysis methods in this article allows answering the main research question of how innovations determine development of the most competitive European economies?

\section{RESULTS}

\section{Quantitative synthesis of the most competitive European economies}

Given the research objective, first the relevance of Global Competitiveness Index (GCI) for assessment of the socioeconomic development of the most competitive economies was carried out. The $\mathrm{GCl}$ is conducted annually by the WEF in order to compare the conditions for economic development in countries around the world. Based on the $\mathrm{GCl}$ from 2017, which includes data from 137 economies, the top ten economies with the highest rank in 
the Global Competitiveness Index 2017-2018 were identified. Over the recent couple of years six European countries remain in the top ten (Table 1). These are Switzerland, the Netherlands, Germany, Sweden, the United Kingdom, and Finland.

Table 1. Comparisons of the top ten economies in the Global Competitiveness Index

\begin{tabular}{|l|c|c|c|c|c|c|}
\hline \multirow{3}{*}{ Economy } & $\mathbf{2 0 1 7 - 2 0 1 8}$ & $\mathbf{2 0 1 6 - 2 0 1 7}$ & 2015-2016 & 2014-2015 & 2013-2014 & 2012-2013 \\
\cline { 2 - 7 } & $\begin{array}{c}\text { Rank } \\
\text { (out of 137) }\end{array}$ & $\begin{array}{c}\text { Rank } \\
\text { (out of 138) }\end{array}$ & $\begin{array}{c}\text { Rank } \\
\text { (out of 140) }\end{array}$ & $\begin{array}{c}\text { Rank } \\
\text { (out of 144) }\end{array}$ & $\begin{array}{c}\text { Rank } \\
\text { (out of 148) }\end{array}$ & $\begin{array}{c}\text { Rank } \\
\text { (out of 144) }\end{array}$ \\
\hline Switzerland & 1 & 1 & 1 & 1 & 1 & 1 \\
\hline United States & 2 & 3 & 3 & 3 & 5 & 7 \\
\hline Singapore & 3 & 2 & 2 & 2 & 2 & 2 \\
\hline Netherlands & 4 & 4 & 5 & 8 & 8 & 5 \\
\hline Germany & 5 & 5 & 4 & 5 & 4 & 6 \\
\hline Hong Kong SAR & 6 & 9 & 7 & 7 & 7 & 9 \\
\hline Sweden & 7 & 6 & 9 & 10 & 6 & 4 \\
\hline United Kingdom & 8 & 7 & 10 & 9 & 10 & 8 \\
\hline Japan & 9 & 8 & 6 & 6 & 9 & 10 \\
\hline Finland & 10 & 10 & 8 & 4 & 3 & 3 \\
\hline
\end{tabular}

Source: own study based on WEF (2017).

As the table illustrates, Switzerland has remained at the forefront of the ranking since 2012, with strong results being at the similar level regarding the different components. The economic results are reflected in strong foundations, including public health, basic education, and a relatively stable macroeconomic environment. The Swiss economy is characterised by high flexibility and its labour markets are recognised as the best functioning in the world (WEF, 2017).

Beside Switzerland, which remains at the top of the overall ranking, also the Netherlands, Germany, Sweden, United Kingdom and Finland maintain their high position in the $\mathrm{GCl}$ 2017-2018. Taking into account the last decade, in the most European countries significant improvements of their innovation ecosystems (e.g. the quality of scientific institutions, company spending on R\&D, and firms' capacity for innovation) can be seen. Data also point out that economic activities in the macroeconomic environment across the EU are currently strengthening (European Union, 2017). However, for a number of European economies, the $\mathrm{GCl}$ illustrates a deterioration in education indicators (e.g. the quality of the education system, primary education, and maths and science). Some weaknesses have also occurred in the transparency of the policymaking process as well as the security situation in several European countries. Based on these synthetic results for six European economies measured by 12 different components, it can be concluded that the $\mathrm{GCl}$ enables a comprehensive assessment of the competitiveness level of individual countries, and thus of their socioeconomic development.

\section{Innovation-driven factors influencing competitiveness}

Furthermore, the aim of the research analysis is to indicate the role of innovation in competitiveness development. In order to examine this relationship, the innovationdriven factors influencing competitiveness were analysed. These $\mathrm{GCl}$ results show that in terms of innovation the best European countries are: Switzerland (1st), Finland (4th), 
Germany (5th), the Netherlands (6th), Sweden (7th), and the United Kingdom (12th). According to the WEF (2017), innovation is essential for economies that approach the limits of knowledge, where the ability to generate growing value only through the integration and adaptation of exogenous technologies tends to disappear. The key feature of such economies is that companies must design and develop state-of-the-art products and processes to sustain a competitive advantage and move to activities with an even higher added value. This development requires an environment that fosters innovative activities by both the public and private sectors, for example through sufficient investments in R\&D, in particular by the private sector, the high-quality R\&D institutions, wide cooperation in research and technological development between industry and universities as well as protection of intellectual property.

A detailed analysis of the ranking positions shows that innovations can be considered an important stimulant of competitiveness development, and therefore the socioeconomic development of the European economies. In order to find out on which factors the development of innovation in European countries is dependent, available $\mathrm{GCl}$ innovation-driven indicators were analysed. The innovation component of the $\mathrm{GCl}$ comprises indicators on the capacity for innovation, the quality of scientific research institutions, university-industry collaboration, government procurement of advanced technology, company spending on R\&D, availability of scientists and engineers, and patent applications (Table 2).

Table 2. Rank of European countries in the GCI 2017-2018 based on innovation-driven indicators

\begin{tabular}{|c|c|c|c|c|c|c|c|c|}
\hline \multirow[b]{2}{*}{ Countries } & \multirow[b]{2}{*}{ 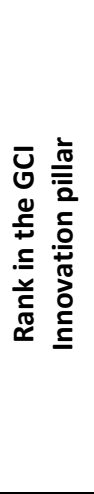 } & \multicolumn{7}{|c|}{ GCI Innovation-related indicators } \\
\hline & & 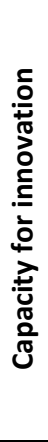 & 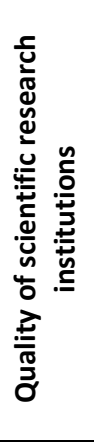 & 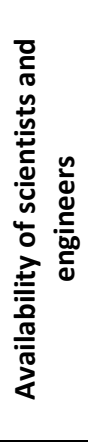 & 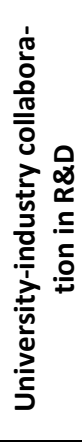 & 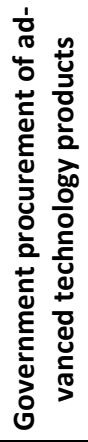 & 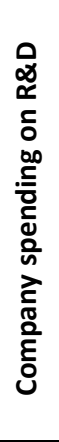 & 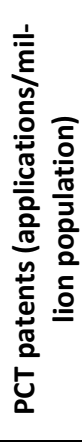 \\
\hline Switzerland & 1 & 1 & 1 & 12 & 1 & 37 & 1 & 3 \\
\hline Finland & 4 & 7 & 8 & 1 & 4 & 20 & 7 & 4 \\
\hline Germany & 5 & 5 & 11 & 11 & 7 & 6 & 4 & 7 \\
\hline Netherlands & 6 & 6 & 4 & 19 & 5 & 19 & 8 & 9 \\
\hline Sweden & 7 & 4 & 13 & 20 & 10 & 17 & 6 & 2 \\
\hline United Kingdom & 12 & 11 & 2 & 17 & 6 & 24 & 14 & 18 \\
\hline
\end{tabular}

Source: own study based on the WEF (2017).

Analyzing the country rank according to these indicators, there is a more differentiated level of development, despite the fact that Switzerland is still a $\mathrm{GCl}$ leader. The ranking indicates that a strong point in Switzerland's competitiveness is the highest place referring to four indicators: capacity for innovation (1st), quality of scientific research institutions (1st), university-industry collaboration in R\&D (1st), and company spending on 
R\&D (1st). However, Switzerland holds a relatively low position in two areas, i.e. availability of scientists and engineers (12th) and government procurement of advanced technology products (37th). It is not only Switzerland but also most of these countries, which show a weak rank in these two last areas except for Finland (1st in the field of availability of scientists and engineers) and Germany (6th in the field of government procurement of advanced technology products). The only indicator illustrating a clearly high position of European countries in the $\mathrm{GCl}$ top ten is extensive business and university collaboration in $R \& D$, where all six countries ranked in the top ten.

Furthermore, it is necessary to highlight that the $\mathrm{GCl}$ indicators measuring the influence of innovation reflect both demand-side as well as supply-side innovation factors. While the supply-side factors are in fact designed to support the innovation process, the demand-side factors aim at addressing and shaping the ecosystem of firms. Based on these indicators, the results for the six most competitive European economies show that demand-side innovation factors comprise measures to stimulate private demand for innovation and intelligent and pre-commercial procurement policies. Based on the $\mathrm{GCl}$ the following demand-side indicators can be identified:

- companies' capacity to innovate,

- fostering innovation by government procurement decisions,

- patent applications.

Supply-side innovation factors rely heavily on the role of research and technological development. They comprise incentives and direct support to R\&D and innovation, skill upgrade, and human resources policies, collaboration for $R \& D$, and networking strategies. Taking into account the $\mathrm{GCl}$ the following supply-side innovation indicators can be determined:

- assessment of the quality of scientific research institutions among the best in the world,

- companies' investment in R\&D,

- collaboration of businesses and universities on R\&D,

- availability of scientists and engineers.

The presented $\mathrm{GCl}$ analysis points to the key lessons and challenges relevant to socioeconomic progress. These factors determine the development of a new quality of socioeconomic development by innovative competitiveness. This requires active cooperation between the state (e.g. legal regulations) and the market (e.g. internationalisation of enterprises, increasing competitiveness), as well as science and politics. It can be concluded that all countries need effective recommendations for innovative competitiveness at microeconomic level which affects the social and economic policy that generates national prosperity.

\section{DISCUSSION}

The research analysis provides, on the one hand, theoretical insights into how innovations determine competitiveness development and, on the other hand, it examines innovationdriven factors influencing the most competitive European economies. The research shows that, from the perspective of socioeconomic development at the macroeconomic level, activities at the microeconomic level play a key role. The study theorises that innovation exerts a positive force on competitiveness. In particular, competitiveness between enterprises is of great interest for many economists, because the companies are the key source 
of real economy, and their behaviour depends largely on the condition, directions and pace of the development of national economies and people's standard of living. Companies contribute - as the key market players - to the emergence of new technologies, products and services, thus striving to gain a competitive advantage, which affects not only socioeconomic development, but also the progress of civilisation.

Considering the turbulent and rapidly changing environment, it can be stated that modern enterprises must constantly verify their basic strategic assumptions because they are under very strong pressure of changes and emerging innovations. Innovation and productivity growth - not economies of scale - will be crucial to achieving competitiveness in the long term. Innovation motivates firms to strive for a competitive advantage, which in turn allows to achieve a technological progress and economic growth at the macro-level. Porter (1990) also pointed out that competitiveness depends on long-term productivity, developed by a business environment that supports continual innovation in products, processes and management. Innovations are perceived as a way for coping with socioeconomic challenges. This study adds to the previous scientific findings that the competitiveness is largely driven by innovation (Brem, Maier \& Wimschneider, 2016; Clark, 1961; Porter, 1990).

Based on these assumptions, the concept of innovative competitiveness has been proposed here. This concept goes beyond the conventional approach of market competition. It leads to a unique combination of innovation and competitive advantage. In spite of synthetic research analysis in this article, the concept of innovative competitiveness is perceived as a relative rather than an absolute concept as it is influenced by different factors. The results of this study demonstrate that the degree of innovation within the $\mathrm{GCl}$ depends on many drivers. Based on innovation-driven indicators, the most competitive European economies were identified. This allows not only for the benchmarking of nations (Berger, 2008) but also showing innovation priorities at the company level. The results of the six most competitive European economies show that both demand-side and supply-side factors are important for innovative competitiveness.

The findings of this study are consistent with the current priorities at the EU level. Innovation has been pushed forward to the top of the priorities, exemplified by strategies such as: the Europe 2020 strategy, as well as the Flagship Initiative "Innovation Union". The EU's innovation policy focuses on a more integrated policy approach for improving the efficiency and effectiveness of research and innovation (R\&I) systems at the regional, national and EU levels (European Union, 2015).

However, presently there has been a strong surge of policy interest in Europe on demand-side instruments (Edler \& Georghiou, 2007). Thus, more attention is paid to the demand-side innovation policies such as: raising awareness, behavioural changes, promoting diffusion and absorption, involvement of (end-users), societal transformation processes, and promoting use of new business models (European Union, 2013). Integrating demandside innovation issues into the mainstream policy instruments (innovation supply / R\&Doriented) is important because it supports companies in using innovation subsidies on R\&D not only for product innovations, but also process innovation (e.g. implementing environmentally friendly technologies and energy efficiency), organisational innovations (changing the business model, implementing disruptive solutions), and market innovations (adapting solutions to other sectors or for internationalisation). The reason for increasing the role of demand-side factors relates to the fact that the nature of innovation has shifted 
over the last decade: from being driven by people working within well-defined borders of corporate or university laboratories towards innovations that are increasingly emerging from the distributed intelligence of the global crowd (Ito \& Howe, 2016). The key factor supporting innovative competitiveness seems to be the constant improvement of framework conditions, based on a stable law-making system, the cohesion of economic policy, and the dialogue between entrepreneurs and politicians.

\section{CONCLUSIONS}

Referring to the main thesis in this article, it can be stated that innovative competitiveness is an important factor not only for stimulating the innovative actions of enterprises but also for effective shaping of socioeconomic development. Changes both in national economies as well as in the global economy, are inherently connected with innovative processes, which, by creating a new economic structure, alter the character and dynamics of economic development. Economies open to ground-breaking innovations, as well as those undergoing a process of "creative destruction", create greater opportunities for dynamic social and economic development. This is done by changing the production structure and creating a new economic order, based on innovative enterprises. It is owing to competitiveness that better and better products are being offered, and companies are forced to innovate and conduct a reasonable pricing policy. The competitive ability of an enterprise depends not only on how it implements its basic economic goals (e.g. profit, profitability and liquidity), but also on whether it takes into account diverse political, legal, economic and social influences.

This article was aimed at analyzing the role of innovation in competitiveness development and identifying the most competitive European economies. Firstly, the framework of an innovative competitiveness was proposed. Secondly, the analysis concerned the most competitive European economies and indicates that innovation is an important factor in competitiveness development. The results provide valuable insights into how innovations determine development of the most competitive European economies. Measuring competitiveness relies on taking into account both supply-side and demand-side indicators. Based on the $\mathrm{GCl}$ the following demand-side indicators were identified: companies' capacity to innovate; fostering innovation by government procurement decisions; patent applications. The supply-side innovation indicators are pertinent to: assessment of the quality of scientific research institutions among the best in the world; companies' investment in R\&D; collaboration of businesses and universities on $R \& D$; availability of scientists and engineers.

Although the research results are encouraging, they are tempered by some limitations. This study focused only on innovation-related issues of the most competitive European countries, and is therefore limited by contextual factors, namely, the GCl's innovation indicators and geography context (selected EU countries). Nonetheless, the research supports theoretical principles extending beyond the countries analysed that can potentially be referred to other $\mathrm{GCl}$ components. Another limitation of the study lies in having focused on the specified indictors, without carrying out further research based on other reliable data, dealing with similar issues. Future research should consider other data sources in order to conduct a comparative analysis, which could provide better insights into influencing factors of innovative competitiveness. The comparative studies could also 
provide both better contextualization of new research results and a comprehensive conceptualization of innovative competitiveness.

\section{REFERENCES}

Atkinson, R.D. (2013). Competitiveness, Innovation and Productivity: Clearing up the Confusion. Washington: The Information Technology \& Innovation Foundation.

Berger, T. (2008). Concepts of national competitiveness. Journal of International Business and Economy, 9(1), 91-111.

Block, J.H., Fisch, C.O., \& van Praag, M. (2017). The Schumpeterian entrepreneur: a review of the empirical evidence on the antecedents, behavior and consequences of innovative entrepreneurship. Industry and Innovation, 24(1), 61-95.

Brem, A., Maier, M., \& Wimschneider, C. (2016). Competitive advantage through innovation: the case of Nespresso. European Journal of Innovation Management, 19(1), 133-148.

Bryman, A., \& Bell, E. (2007). Business research methods. 2ed edition, Oxford: Oxford University Press.

Clark, J.M. (1961). Competition as a Dynamic Process. Washington: Brookings Institution.

Crowther, D., \& Lancaster, G. (2008). Research Methods: A Concise Introduction to Research in Management and Business Consultancy. 2ed edition, New York: Taylor \& Francis.

De Soto, H.J. (2008). The Austrian School Market Order and Entrepreneurial Creativity. Cheltenham, Northampton: Edward Elgar.

Diamond, A.M. (2006). Schumpeter's Creative Destruction: A Review of the Evidence. Journal of Private Enterprise, 22(1), 120-146.

Edler, J., \& Georghiou, L. (2007). Public procurement and innovation - Resurrecting the demand side. Research Policy, 36(7), 949-963.

Edler, J., Georghiou, L., Blind, K., \& Uyarra, E. (2012). Evaluating the demand side: New challenges for evaluation. Research Evaluation, 21(1), 33-47.

Edler, J., \& Yeow, J. (2016). Connecting demand and supply: the role of intermediation in public procurement of innovation. Research Policy, 45(2), 414-426.

Easterby-Smith, M., Thorpe, R., \& Lowe, A. (2002). Management Research: An Introduction. 2ed edition, London: Sage.

European Union (2013). Trend report: Un-locking the potential of business and societal innovation; how to scale-up successful new business and production models? Business Innovation Observatory. Retrieved from: https://ec.europa.eu/growth/content/first-trend-report\%E2\%80\%98un-locking-potential-business-and-societal-innovation\%E2\%80\%99_en

European Union (2015). Supply and Demand Side Innovation Policies. Annexes of First policy brief. Luxembourg: Publications Office of the European Union, doi: 10.2777/43249.

European Union (2017). Current challenges in fostering the European innovation ecosystem. Publications Office of the European Union, Luxembourg, doi:10.2760/768124, JRC108368.

von Hayek, F.A. (2002). Competition as a Discovery Procedure. The Quartely Journal of Austrian Economics, 5(3), 9-23.

Ito, J., \& Howe, J. (2016). Whiplash: How to Survive Our Faster Future. New York: Grand Central Publishing.

Johnston, M.P. (2014). Secondary Data Analysis: A Method of which the Time Has Come. Qualitative and Quantitative Methods in Libraries, QQML(3), 619-626. 
Listra, E. (2015). The concept of competition and the objectives of competitors. 20th International Scientific Conference Economics and Management - 2015 (ICEM-2015). Procedia - Social and Behavioral Sciences, 213, 25-30.

Miles, I., \& Rigby, J. (2013). Demand-Led Innovation. In: D. Cox, J. Rigby (eds) Innovation Policy Challenges for the 21st Century (pp. 36-63). New York: Routledge.

Mowery, DC., \& Rosenberg, N. (1979). The influence of market demand upon innovation: a critical review of some recent empirical studies. Research Policy, 8, 103-153.

OECD (1996). Globalization and Competitiveness: Relevant Indicators. OECD Science, Technology and Industry Working Papers, 5.

Porter, M.E. (1990). The competitive advantage of nations. Harvard Business Review, 68(2), 73-93.

Porter, M.E., \& Rivkin, J.W. (2012). The Looming Challenge to U.S. Competitiveness. Harvard Business Review, 90(3), 54-61.

Reinert, H., \& Reinert, E.S. (2012). Creative Destruction in Economics: Nietzsche, Sombart, Schumpeter. In: J. Backhaus and W. Drechsler (eds) Friedrich Nietzsche 1844-2000: Economy and Society (pp. 5-7). Boston: Kluwer.

Schumpeter, J.A. (1934). The Theory of Economic Development: An Inquiry Into Profits, Capital, Credit, Interest, and the Business Cycle. London: Transaction Publishers.

Schumpeter, J.A. (1939). Business Cycles, A Theoretical, Historical and Statistical Analysis of Capitalist Process. London: Porcupine Press.

Schumpeter, J.A. (2008). Capitalism, Socialism, and Democracy. Harper Perennial Modern Classics. Third Edition, New York: Harper Perennial Modern Thought.

Siudek, T., \& Zawojska, A. (2014). Competitiveness in the Economic Concepts, Theories and Empirical research. Acta Scientiarum Polonorum. Oeconomia, 13(1), 91-108.

Smith, A. [1776] (2007). An Inquiry into the Nature and Causes of the Wealth of Nations. MetaLibri Digital Library: Lausanne. Retrieved from: https://www.ibiblio.org/ml/libri/s/SmithA_WealthNations_p.pdf

Steckel, R.H. (1995). Stature and the Standard of Living. Journal of Economic Literature, XXXIII, 1903-1940.

Stiglitz, J.E. (2002). Competition and Competitiveness in a New Economy. In: H. Handler and C. Burger (eds) Competition and Competitiveness in a New Economy (pp. 11-26). Vienna: Austrian Federal Ministry for Economic Affairs.

UNCTAD (2009). The relationship between competition, competitiveness and development. TD/B/COM.2/CLP/30. Retrieved from: http://unctad.org/Sections/ditc_ccpb/docs/ditc_ccpb0020_en.pdf

Urbaniec, M. (2018). Sustainable Entrepreneurship: Innovation-Related Activities in European Enterprises. Polish Journal of Environmental Studies, 27(4), 1773-1779.

Urbaniec, M., \& Gerstlberger, W. (2011). Innovation in environment-oriented networks: Influence factors from case study and survey research. Management of Environmental Quality: An International Journal, 22(6), 686-704.

Vartanian, T.P. (2011). Secondary data analysis. New York, NY: Oxford.

Vivarelli, M. (2013). Is entrepreneurship necessarily good? Microeconomic evidence from developed and developing countries. Industrial and Corporate Change, 22(6), 1453-1495.

WEF (2017). The Global Competitiveness Report 2017-2018. Geneva: World Economic Forum. 


\section{Author}

\section{Maria Urbaniec}

Assistant Professor at the Department of Entrepreneurship and Innovation of the Cracow University of Economics. She received her PhD in Economics and her MA in Business Economics from the International Graduate School Zittau at the Technische Universität Dresden (Germany). Her research focuses on sustainable entrepreneurship, eco-innovation, and industry 4.0.

Correspondence to: Maria Urbaniec, PhD, Cracow University of Economics, Department of Entrepreneurship and Innovation, ul. Rakowicka 27, 31-510 Kraków, Poland, e-mail: maria.urbaniec@uek.krakow.pl

ORCID (i) http://orcid.org/0000-0001-8307-8396

\section{Acknowledgements and Financial Disclosure}

The article came into being within the project no. 021/RID/2018/19 financed by the Ministry of Science and Higher Education of the Republic of Poland within "Regional Initiative of Excellence" Programme for 2019-2022 conducted by the Cracow University of Economics.

\section{Copyright and License}

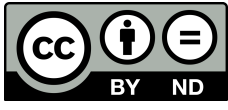

This article is published under the terms of the Creative Commons

Attribution - NoDerivs (CC BY-ND 4.0) License http://creativecommons.org/licenses/by-nd/4.0/

Published by the Centre for Strategic and International Entrepreneurship - Krakow, Poland

The journal is co-financed in the years $2019-2020$ by the Ministry of Sci- 
